Short Communication

\title{
Comparative Study on Electrochemical Corrosion Behavior of B500SD Carbon Steel and 2205 Duplex Stainless Steel Exposed to Concrete Pore Solution Containing Chloride Ions
}

\author{
Weiling Teng ${ }^{*}$, Xiaofang $\mathrm{Li}$ \\ School of Civil Engineering, Xijing University, Xi'an 710123, China \\ *E-mail: weiling_1206@sina.com
}

doi: $10.20964 / 2021.07 .54$

Received: 6 April 2021/ Accepted: 11 May 2021 / Published: 31 May 2021

\begin{abstract}
In this work, a comparative study was done on electrochemical corrosion behavior of B500SD carbon steel and 2205 duplex stainless steel rebars immersed into concrete pore solution containing chloride ions. An electrochemical impedance spectroscopy (EIS) analysis was conducted to consider the corrosion resistance of steel rebars in various environmental conditions such as $\mathrm{pH}$, temperature and chloride ion concentration. The EIS results exhibit that the double-layer capacitance value decreased as $\mathrm{pH}$-value gradually increased, which indicates that the size of passive film was enhanced, causing an improvement of the protective ability. Corrosion resistance of both steel rebars was increased by a temperature drop from $45^{\circ} \mathrm{C}$ to $20^{\circ} \mathrm{C}$. The electrochemical findings reveal that 2205 duplex stainless steel exhibits a higher corrosion resistance and higher impedance with a higher durability in different conditions than B500SD carbon steel rebar which can be associated with the existence of Cr noble metal in stainless steel composition.
\end{abstract}

Keywords: Electrochemical corrosion behavior; 2205 duplex stainless steel; B500SD carbon steel; Concrete pore solution; Electrochemical impedance spectroscopy

\section{FULL TEXT}

(C) 2021 The Authors. Published by ESG (www.electrochemsci.org). This article is an open access article distributed under the terms and conditions of the Creative Commons Attribution license (http://creativecommons.org/licenses/by/4.0/). 